\title{
Serum creatinine in patients with advanced liver disease is of limited value for identification of moderate renal dysfunction: Are the equations for estimating renal function better?
}

\author{
Jillian MacAulay BSc${ }^{1}$, Kara Thompson MSc${ }^{2}$, Bryce A Kiberd $\mathrm{MD}^{3}$, David C Barnes MD ${ }^{4}$, Kevork M Peltekian MD ${ }^{1}$
}

\begin{abstract}
J MacAulay, K Thompson, BA Kiberd, DC Barnes, KM Peltekian. Serum creatinine in patients with advanced liver disease is of limited value for identification of moderate renal dysfunction: Are the equations for estimating renal function better? Can J Gastroenterol 2006;20(8):521-526.
\end{abstract}

BACKGROUND: The Cockcroft-Gault formula (CGF) is used to estimate the glomerular filtration rate (GFR) based on serum creatinine $(\mathrm{Cr})$ levels, age and sex. A new formula developed by the Modification of Diet in Renal Disease (MDRD) Study Group, based on the patient's Cr levels, age, sex, race and serum urea nitrogen and serum albumin levels, has shown to be more accurate. However, the best formula to identify patients with advanced liver disease (ALD) and moderate renal dysfunction (GFR $60 \mathrm{~mL} / \mathrm{min} / 1.73 \mathrm{~m}^{2}$ or less) is not known. The aim of the present study was to compare calculations of GFR, using published formulas (excluding those requiring urine collections) with standard radionuclide measurement of GFR in patients with ALD. METHODS: Fifty-seven consecutive subjects (40\% women) with a mean age of 50 years (range 16 to 67 years) underwent 99 m-technetiumdiethylenetriamine pentaacetic acid ( ${ }^{99} \mathrm{~m}$ Tc-DTPA) (single injection) radionuclide measurement of GFR. To calculate GFR, three formulas were used: the reciprocal of $\mathrm{Cr}$ multiplied by $100(100 / \mathrm{Cr})$, the CGF and the MDRD formulas. Pearson's correlation coefficient ( $r$ ) and BlandAltman analyses of agreement were used to analyze the association between ${ }^{99} \mathrm{~m}$ Tc-DTPA clearance and the three equations for GFR.

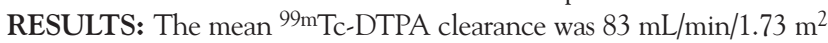
(range $28 \mathrm{~mL} / \mathrm{min} / 1.73 \mathrm{~m}^{2}$ to $173 \mathrm{~mL} / \mathrm{min} / 1.73 \mathrm{~m}^{2}$ ). Mean calculated GFRs by $100 / \mathrm{Cr}$, the CGF and the MDRD formula were $106 \mathrm{~mL} / \mathrm{min} / 1.73 \mathrm{~m}^{2}, 98 \mathrm{~mL} / \mathrm{min} / 1.73 \mathrm{~m}^{2}$ and $86 \mathrm{~mL} / \mathrm{min} / 1.73 \mathrm{~m}^{2}$, respectively. Regression analysis showed good correlation between radionuclide GFR and calculated GFR with $\mathrm{r}_{(100 / \mathrm{Cr})}=0.74, \mathrm{r}_{(\mathrm{CGF})}=0.80$, $r_{(M D R D)}=0.87$, all at $P \leq 0.0001$. The MDRD formula provided the least bias. The Bland-Altman plot showed best agreement between GFR calculated by the MDRD formula and ${ }^{99} \mathrm{~m}$ Tc-DTPA clearance, with only $3 \mathrm{~mL} / \mathrm{min} / 1.73 \mathrm{~m}^{2}$ overestimation. There was higher variability between radionuclide GFR and calculated GFR by the CGF and by $100 / \mathrm{Cr}$. Although there was no difference in precision, GFR calculated by the MDRD formula had the best overall accuracy. The sensitivity and specificity for detection of moderate renal dysfunction by the MDRD formulas were $73 \%$ and $87 \%$, respectively.

CONCLUSIONS: Among the Cr-based GFR formulas, the MDRD formula showed a larger proportion of agreement with radionuclide GFR in patients with ALD. In clinical practice, the MDRD is the best formula for detection of moderate renal dysfunction among those with ALD.

Key Words: Cirrhosis; Cockcroft-Gault formula; Creatinine; Glomerular filtration rate; Liver disease

\author{
La créatinine sérique chez les patients atteints \\ d'une maladie hépatique avancée est peu \\ efficace pour dépister une dysfonction rénale \\ modérée : Les équations visant à évaluer la \\ fonction rénale sont-elles préférables?
}

HISTORIQUE : La formule de Cockcroft-Gault (FCG) sert à évaluer le taux de filtration glomérulaire (TFG) d'après les taux de créatinine $(\mathrm{Cr})$ sérique, l'âge et le sexe. Une nouvelle formule, mise au point par le groupe d'étude sur la modification du régime en cas de maladie rénale (MRMR), fondée sur le taux de Cr, l'âge, le sexe, la race et les taux d'azote uréique sérique et d'albumine sérique du patient, s'est révélée plus exacte. Cependant, on ne connaît pas la meilleure formule pour repérer les patients atteints d'une maladie hépatique avancée (MHA) et d'une dysfonction rénale modérée (TFG $60 \mathrm{~mL} / \mathrm{min} / 1,73 \mathrm{~m}^{2}$ ). La présente étude visait à comparer les calculs de TFG au moyen des formules publiées (à l'exception de celles exigeant un prélèvement d'urine) à la mesure radionucléide normalisée du TFG chez les patients atteints d'une MHA. MÉTHODOLOGIE : Cinquante-sept sujets consécutifs (40\% de femmes) d'un âge moyen de 50 ans (fourchette de 16 à 67 ans) ont subi une mesure radionucléide du TGF au technétium $99 \mathrm{~m}$ d'acide diéthylène triamino-pentaacétique ( ${ }^{99 \mathrm{~m}} \mathrm{Tc}$ DTPA) (une seule injection). Pour calculer le TFG, trois formules ont été utilisées, soit la réciproque de la $\mathrm{Cr}$ multipliée par 100 (100/Cr), la FCG et la formule MRMR. Le coefficient de corrélation de Pearson ( $r$ ) et les analyses de concordance de BlandAltman ont été utilisés pour analyser le lien entre la clairance du ${ }^{99} \mathrm{~m} T \mathrm{~T}$ DTPA et les trois équations du TGF.

RÉSULTATS : La clairance moyenne de ${ }^{99 \mathrm{~m}} \mathrm{Tc}$ DTPA était de $83 / \mathrm{mL} / \mathrm{min} / 1,73 \mathrm{~m}^{2}$ (fourchette de $28 / \mathrm{mL} / \mathrm{min} / 1,73 \mathrm{~m}^{2}$ à $173 / \mathrm{mL} / \mathrm{min} / 1,73 \mathrm{~m}^{2}$ ). Le TFG moyen calculé par 100/Cr, la FCG et la formule MRMR étaient de $106 \mathrm{~mL} / \mathrm{min} / 1,73 \mathrm{~m}^{2}$, de $98 \mathrm{~mL} / \mathrm{min} / 1,73 \mathrm{~m}^{2}$ et de $86 \mathrm{~mL} / \mathrm{min} / 1,73 \mathrm{~m}^{2}$, respectivement. L'analyse de régression a démontré une bonne corrélation entre le TFG radionucléide et le TFG calculé par $\mathrm{r}_{(100 / \mathrm{Cr})}=0,74, \mathrm{r}_{(\mathrm{FCG})}=0,80, \mathrm{r}_{(\mathrm{MRMR})}=0,87$, tous à $\mathrm{P} \leq 0,0001$. La formule MRMR était la moins biaisée. La courbe de Bland-Altman révélait la meilleure concordance entre le TFG calculé par la formule MRMR et la clairance ${ }^{99 \mathrm{~m}} \mathrm{~T}_{\mathrm{c}}$ DTPA, avec une surestimation de seulement $3 \mathrm{~mL} / \mathrm{min} / 1,73 \mathrm{~m}^{2}$. On constatait une plus grande variabilité entre le TFG radionucléide et le TFG calculé par la FCG et le 100/Cr. Même s'il n'y avait aucune différence de précision, le TFG calculé par la formule MRMR était la plus précise. La sensibilité et la spécificité de détection d'une dysfonction rénale modérée par la formule MRMR étaient de $73 \%$ et de $87 \%$, respectivement.

CONCLUSIONS : Parmi les formules pour calculer le TFG fondées sur la Cr, la formule MRMR démontrait la meilleure concordance avec le TFG radionucléide chez les patients atteints d'une MHA. En pratique clinique, la formule MRMR est la meilleure pour déceler une dysfonction rénale modérée chez les personnes atteintes d'une MHA.

\footnotetext{
${ }^{1}$ Department of Medicine, Division of Gastroenterology (Hepatology Services); ${ }^{2}$ Office of Medical Outcomes Research and Biostatistics;

${ }^{3}$ Division of Nephrology; ${ }^{4}$ Department of Diagnostic Imaging, Division of Nuclear Medicine, Dalhousie University, Halifax, Nova Scotia Correspondence and reprints: Dr Kevork M Peltekian, Hepatology Services, 1278 Tower Road, Victoria General Site, Room 6-302, Halifax,

Nova Scotia B3H 2Y9. Telephone 902-473-2898, fax 902-473-2783, e-mail Kevork.Peltekian@dal.ca

Received for publication July 12, 2005. Accepted January 25, 2006
} 
$\mathrm{B}_{\mathrm{d}}^{\mathrm{o}}$ th worldwide and in Canada, the burden of chronic liver disease and cirrhosis is significant $(1,2)$. Renal dysfunction is a major complication that accompanies cirrhosis and is associated with poor prognosis (3), especially after liver transplantation. Serum creatinine $(\mathrm{Cr})$ is increasingly being incorporated into prognostic models for patients with decompensated cirrhosis $(4,5)$ and for allocation of organs for liver transplantation (6). However, renal dysfunction in patients with advanced liver disease (ALD) is often difficult to assess due to poor methods for estimating renal function in this patient population $(7-10)$.

In general, $\mathrm{Cr}$ and urea clearance are used to estimate glomerular filtration rate (GFR). Using Cr-based methods to estimate GFR in ALD patients is problematic for multiple reasons. Decline in hepatic functional capacity results in decreased creatine production and lower serum Cr levels. ALD patients are known to have less skeletal muscle mass, resulting in diminished creatine storage and less conversion of creatine to Cr. All of these factors lead to a decreased serum Cr level in ALD patients, making $\mathrm{Cr}$ an unreliable factor in estimating GFR (11). Analytical methods used to determine the serum Cr concentration can also result in variability in Cr levels. The kinetic Jaffe method is commonly used to measure serum $\mathrm{Cr}$ levels and can be interfered with by elevated serum bilirubin levels, resulting in false low Cr levels (12).

Many formulas have been published to estimate GFR using serum Cr levels. The simplest is the reciprocal of serum $\mathrm{Cr}$ calculated as $1 / \mathrm{Cr}$, with $\mathrm{Cr}$ in $\mathrm{mg} / \mathrm{dL}$ (13). The most widely used formula to estimate filtration is the Cockcroft-Gault formula (CGF):

$$
\frac{(140-\text { age }) \times \text { weight }}{\mathrm{Cr} \times 72}
$$

with age in years, weight in $\mathrm{kg}$ and $\mathrm{Cr}$ in $\mathrm{mg} / \mathrm{dL}$; this formula is modified for women (14):

$$
\frac{(140-\text { age }) \times \text { weight }}{\mathrm{Cr} \times 85}
$$

In 1999, the Modification of Diet in Renal Disease (MDRD) Study Group published a more accurate method to estimate GFR from serum Cr based on demographic and serum variables:

$170 \times(\mathrm{Cr})^{-0.999} \times(\text { age })^{-0.176} \times(0.762$ if patient is female $) \times$

$(1.18$ if patient is black $) \times(\text { urea nitrogen })^{-0.17} \times(\text { albumin })^{+0.318}$

with age in years, $\mathrm{Cr}$, urea nitrogen and albumin in $\mathrm{mg} / \mathrm{dL}$ (15). These equations have been validated in patients with end-stage renal disease $(16,17)$ and in renal transplant recipients $(18,19)$. The MDRD formula has been used to estimate renal function in liver disease and transplantation (20-22). Recently, Skluzacek et al (23) compared renal with plasma clearance of 125 -iodine $\left({ }^{125} \mathrm{I}\right)$ iothalamate, as well as compared the CGF with the MDRD formula to estimate renal function in a small patient group with ALD. Gonwa et al (24) evaluated the performance of these formulas in a large database for both pre- and postliver transplantation. Neither study reported on bias, precision or accuracy of the various calculated GFR formulas. The proper validation of the MDRD formula in ALD patients is important because serum $\mathrm{Cr}$, urea nitrogen and albumin levels are variables that change with ALD. More importantly, these formulas need to be assessed in the context of identifying patients with ALD who truly have significant renal dysfunction (stage 3 or worse as defined by the Kidney Disease Outcomes Quality Initiative [KDOQI] Chronic Kidney Disease Classification) (25).

The aim of the present study was to compare estimates of GFR using published formulas (excluding those requiring urine collections) with standard radionuclide measurements of GFR in patients with ALD. We used the reciprocal for $\mathrm{Cr}$, the CGF and the MDRD formulas for GFR estimation.

\section{METHODS}

Fifty-seven consecutive patients with ALD (excluding those presenting with fulminant liver failure) referred for liver transplantation assessment underwent routine radionuclide GFR measurement using $99 \mathrm{~m}$-technetium-diethylenetriamine pentaacetic acid ( ${ }^{99 m}$ Tc-DTPA) by the Russell two-point sample technique following single bolus intravenous injection (26). All patients undergoing radionuclide assessment had clinically stable hemodynamics and renal function. ${ }^{99 \mathrm{~m}} \mathrm{Tc}$-DTPA clearance was used as the reference GFR because it has the same volume distribution, transit time and plasma clearance as inulin (Pearson's correlation coefficient $[\mathrm{r}]=0.98)(27)$.

Height and weight were measured on the morning of the study. All patients ingested $500 \mathrm{~mL}$ to $750 \mathrm{~mL}$ of water over a $2 \mathrm{~h}$ period before the procedure. An intravenous bolus of $5 \mathrm{mCi}$ of ${ }^{99 \mathrm{~m}}$ Tc-DTPA (DRAXIMAGE Inc, Canada) was administered into one arm with the residual activity in the syringe checked after injection through imaging. The blood samples were drawn from the contralateral arm. All chemical analyses and gamma counting were performed by routine methods at the Queen Elizabeth II Health Sciences Centre (Halifax, Nova Scotia). Clearances were calculated using standard formulas and were normalized to a body surface area of $1.73 \mathrm{~m}^{2}$.

Demographic and clinical data were retrieved from the liver transplantation database. The reciprocal of $\mathrm{Cr}$, the CGF and the MDRD formulas were used; for conversion, serum $\mathrm{Cr}$ of $1 \mathrm{mg} / \mathrm{dL}$ equalled $88.4 \mu \mathrm{mol} / \mathrm{L}$. To render the calculated GFR comparable, the reciprocal of $\mathrm{Cr}$ in $\mathrm{mg} / \mathrm{dL}$ multiplied by 100 (100/Cr) was used.

All data were entered into Microsoft Excel (Microsoft Co, USA). Simple statistics (mean difference, relative percentage difference) were used to compare the radionuclide GFR with each of the other three methods using SAS version 8.2 (SAS Institute Inc, USA). The association between GFR and formulas was evaluated using Pearson's r, as well as the Bland-Altman plot (28) to describe the agreement using S-Plus 6.1 (Insightful, USA). All variables are given as mean \pm SD or with $\pm 95 \%$ CI. $\mathrm{P}<0.05$ was considered significant.

The mean absolute difference between GFR ( $99 \mathrm{~m} \mathrm{Tc}$-DTPA clearance) and calculated GFR was used to calculate bias. The precision of the formulas were expressed as the root mean square error. The accuracy was measured as the proportion of GFR estimates within 10\%, 30\% and 50\% deviation of the reference GFR. Finally, sensitivity and specificity for each of the calculated GFR were determined at the cut-off point of $60 \mathrm{~mL} / \mathrm{min} / 1.73 \mathrm{~m}^{2}$ (moderate renal dysfunction).

\section{RESULTS}

Etiology of ALD varied among the patients studied, with Laennecs cirrhosis and cryptogenic cirrhosis being most prevalent. Severity of ALD was measured using the Child-Pugh score with 14\% Child-Pugh class A, 33\% Child-Pugh class B and 53\% Child-Pugh class C. All but one patient were Caucasian. Mean height and weight were $1.65 \mathrm{~m}$ and $81 \mathrm{~kg}$, respectively; 
TABLE 1

Characteristics of patients $(n=57)$ with advanced liver disease

\begin{tabular}{lc}
\hline Characteristics & \\
\hline Sex, male & $34(60)$ \\
Age, years & $50 \pm 11$ \\
Height, cm & $165 \pm 11$ \\
Weight, $\mathrm{kg}$ & $81 \pm 17$ \\
Caucasian & $56(98)$ \\
Diabetes & $13(23)$ \\
Etiology of liver disease & \\
Laennecs cirrhosis & $17(30)$ \\
Cryptogenic cirrhosis including & $15(26)$ \\
$\quad$ nonalcoholic steatohepatitis & \\
Viral hepatitis B or C & $11(19)$ \\
Primary sclerosing cholangitis & $7(12)$ \\
Primary biliary cirrhosis & $6(11)$ \\
Autoimmune hepatitis & $2(4)$ \\
Metabolic liver diseases & $2(4)$ \\
Other & $3(5)$ \\
Mean arterial pressure, mmHg & $86 \pm 11$ \\
Creatinine (range $65 \mu \mathrm{mol} / \mathrm{L}$ to $115 \mu \mathrm{mol} / \mathrm{L})$ & $87 \pm 35$ \\
Urea nitrogen (range $5.2 \mathrm{mmol} / \mathrm{L}$ to $9.5 \mathrm{mmol} / \mathrm{L})$ & $6.5 \pm 4.7$ \\
Albumin (range $36 \mathrm{~g} / \mathrm{L}$ to $50 \mathrm{~g} / \mathrm{L})$ & $28 \pm 6$ \\
Child-Pugh class & $8(14)$ \\
A & $19(33)$ \\
B & $30(53)$ \\
C &
\end{tabular}

Results reported as $n$ (\%) or mean $\pm S D$

23\% were diabetic. Mean arterial pressure was $86 \mathrm{mmHg}$. Mean serum $\mathrm{Cr}$ and urea levels were within normal limits. Mean serum albumin level was lower than normal; mean serum total bilirubin level and the international normalized ratio were elevated above the upper limit of normal in the patients studied. Characteristics of the patients studied are summarized in Table 1.

The mean ${ }^{99 \mathrm{~m}} \mathrm{Tc}$-DTPA clearance was $83 \mathrm{~mL} / \mathrm{min} / 1.73 \mathrm{~m}^{2}$ (range $28 \mathrm{~mL} / \mathrm{min} / 1.73 \mathrm{~m}^{2}$ to $173 \mathrm{~mL} / \mathrm{min} / 1.73 \mathrm{~m}^{2}$ ). Mean calculated GFR for $100 / \mathrm{Cr}$, the CGF and the MDRD formula was $106 \mathrm{~mL} / \mathrm{min} / 1.73 \mathrm{~m}^{2}, 98 \mathrm{~mL} / \mathrm{min} / 1.73 \mathrm{~m}^{2}$ and $86 \mathrm{~mL} / \mathrm{min} / 1.73 \mathrm{~m}^{2}$, respectively. Even in patients with reference radionuclide GFR less than or equal to $60 \mathrm{~mL} / \mathrm{min} / 1.73 \mathrm{~m}^{2}$, the serum Cr level ranged between $54 \mu \mathrm{mol} / \mathrm{L}$ and $263 \mu \mathrm{mol} / \mathrm{L}$ (median $104 \mu \mathrm{mol} / \mathrm{L}$ ).

The simple statistics summarizing the comparison of each method with ${ }^{99 \mathrm{~m}} \mathrm{Tc}$-DTPA are shown in Table 2 . The mean MDRD did not differ from the mean ${ }^{99 m}$ Tc-DTPA clearance $(\mathrm{P}=0.414)$. Both $100 / \mathrm{Cr}$ and the CGF overestimated the mean ${ }^{99 m}$ Tc-DTPA clearance $(\mathrm{P}<0.001)$. All three methods demonstrated large standard errors in the difference, suggesting limited precision. The regression analysis showed good degrees of association with Pearson's $\mathrm{r}_{(100 / \mathrm{Cr})}=0.74$, $\mathrm{r}_{(\mathrm{CGF})}=0.80$ and $\mathrm{r}_{(\mathrm{MDRD})}=0.87$ (Figure 1), all at $\mathrm{P} \leq 0.0001$. Pearson's coefficient of determination or the $\mathrm{r}^{2}$ value was best associated with the MDRD formula and 99mTc-DTPA (Table 2). Figure 2 summarizes the accuracy of the three calculated GFR formulas within $10 \%, 30 \%$ and $50 \%$; the MDRD formula was the best among the three formulas.
TABLE 2

Results of statistical analysis of the Modification of Diet in Renal Disease (MDRD) formula, the reciprocal of creatinine (Cr) multiplied by $100(100 / \mathrm{Cr})$ and the Cockcroft-Gault formula (CGF) compared with 99 m-technetiumdiethylenetriamine pentaacetic acid ( ${ }^{99 \mathrm{~m} T c-D T P A)}$ clearance

\begin{tabular}{|c|c|c|c|}
\hline & \multicolumn{3}{|c|}{$\begin{array}{l}\text { Comparison with } \\
\text { 99mTc-DTPA clearance }\end{array}$} \\
\hline & MDRD formula & $100 / \mathrm{Cr}$ & $\begin{array}{l}\text { Cockcroft- } \\
\text { Gault formula }\end{array}$ \\
\hline Mean, $\mathrm{mL} / \mathrm{min} / 1.73 \mathrm{~m}^{2}$ & $\begin{array}{c}86.21 \\
(76.32,96.10)\end{array}$ & $\begin{array}{c}106.49 \\
(112.36,132.32)\end{array}$ & $\begin{array}{c}98.11 \\
(103.79,132.70)\end{array}$ \\
\hline $\begin{array}{l}\text { Mean difference, } \\
\mathrm{mL} / \mathrm{min} / 1.73 \mathrm{~m}^{2}\end{array}$ & $\begin{array}{c}3.45 \\
(-4.94,11.84)\end{array}$ & $\begin{array}{c}23.74 \\
(15.23,32.24)\end{array}$ & $\begin{array}{c}15.36 \\
(8.32,22.40)\end{array}$ \\
\hline $\begin{array}{l}\text { Percentage } \\
\text { difference, \% }\end{array}$ & $\begin{array}{c}4.00 \\
(-5.73,20.39)\end{array}$ & $\begin{array}{c}22.29 \\
(14.30,30.28)\end{array}$ & $\begin{array}{c}15.66 \\
(8.48,22.83)\end{array}$ \\
\hline $\begin{array}{l}\text { Relative percentage } \\
\text { difference, } \%\end{array}$ & $\begin{array}{c}4.17 \\
(-5.97,14.31)\end{array}$ & $\begin{array}{c}28.68 \\
(18.40,38.96)\end{array}$ & $\begin{array}{c}18.56 \\
(10.05,27.07)\end{array}$ \\
\hline$r$ & 0.874 & 0.739 & 0.804 \\
\hline$r^{2}$ & 0.764 & 0.546 & 0.647 \\
\hline $\begin{array}{l}\text { Bias (mean absolute } \\
\text { difference), } \\
\mathrm{mL} / \mathrm{min} / 1.73 \mathrm{~m}^{2}\end{array}$ & $\begin{array}{c}23.42 \\
(17.78,29.08)\end{array}$ & $\begin{array}{c}30.99 \\
(24.37,37.61)\end{array}$ & $\begin{array}{c}23.59 \\
(18.44,28.75)\end{array}$ \\
\hline $\begin{array}{l}\text { Precision (root mean } \\
\text { square of difference), } \\
\mathrm{mL} / \mathrm{min} / 1.73 \mathrm{~m}^{2}\end{array}$ & $\begin{array}{c}31.53 \\
(23.78,37.72)\end{array}$ & $\begin{array}{c}39.66 \\
(29.19,47.89)\end{array}$ & $\begin{array}{c}30.45 \\
(23.15,36.31)\end{array}$ \\
\hline Sensitivity*, \% & 72.72 & 27.27 & 45.45 \\
\hline Specificity* $\%$ & 86.96 & 95.65 & 93.48 \\
\hline $\begin{array}{l}95 \% \text { limit of } \\
\text { agreement }\end{array}$ & $(-78.10,51.58)$ & $(-81.38,21.96)$ & $(-72.04,26.75)$ \\
\hline
\end{tabular}

95\% Cls shown in parentheses. *Sensitivity and specificity calculated for moderate renal dysfunction (glomerular filtration rate $60 \mathrm{~mL} / \mathrm{min} / 1.73 \mathrm{~m}^{2}$ or less); $r$ Pearson's correlation coefficient; $r^{2}$ Pearson's coefficient of determination

An alternative statistical method to compare methods of measurement is the Bland-Altman plot, which shows agreement between a test method and the reference. It uses 95\% limits of agreement to define the range within which most differences between measurements lie (28). The Bland-Altman plot revealed that the $100 / \mathrm{Cr}$ formula resulted in a mean overestimation of $24 \mathrm{~mL} / \mathrm{min} / 1.73 \mathrm{~m}^{2}$ with limits of agreement between $-81 \mathrm{~mL} / \mathrm{min} / 1.73 \mathrm{~m}^{2}$ and $22 \mathrm{~mL} / \mathrm{min} / 1.73 \mathrm{~m}^{2}$ (Figure 3A). The CGF overestimated the mean by $15 \mathrm{~mL} / \mathrm{min} / 1.73 \mathrm{~m}^{2}$ with limits of $-72 \mathrm{~mL} / \mathrm{min} / 1.73 \mathrm{~m}^{2}$ and $27 \mathrm{~mL} / \mathrm{min} / 1.73 \mathrm{~m}^{2}$ (Figure 3B). The MDRD formula had the highest level of agreement with GFR measured by ${ }^{99 \mathrm{~m}} \mathrm{Tc}-\mathrm{DTPA}$ clearance, with an overestimation of $3 \mathrm{~mL} / \mathrm{min} / 1.73 \mathrm{~m}^{2}$, and limits of agreement between $-78 \mathrm{~mL} / \mathrm{min} / 1.73 \mathrm{~m}^{2}$ and $52 \mathrm{~mL} / \mathrm{min} / 1.73 \mathrm{~m}^{2}$ (Figure 3C). These figures had a GFR of $60 \mathrm{~mL} / \mathrm{min} / 1.73 \mathrm{~m}^{2}$ or less; the difference was the least between the reference GFR and the MDRD formula.

Table 2 also provides the sensitivity and specificity of each calculated GFR formula for moderate renal dysfunction (cut-off point $60 \mathrm{~mL} / \mathrm{min} / 1.73 \mathrm{~m}^{2}$ ). The sensitivity was best for the MDRD formula.

\section{DISCUSSION}

The data shown here confirm previous studies stating that renal dysfunction is underestimated in patients with ALD (7-9). 


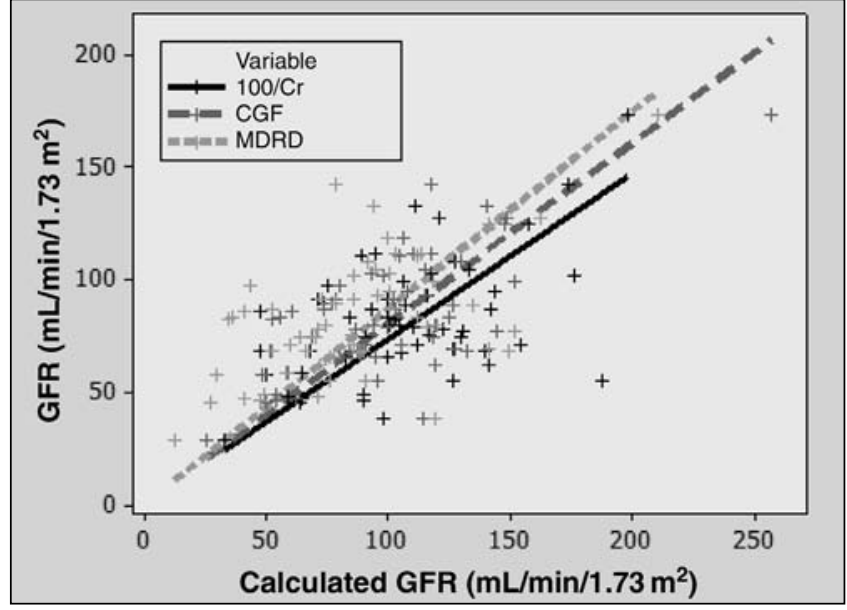

Figure 1) Relationship of glomerular filtration rate (GFR) measured by $99 m$-technetium-diethylenetriamine pentaacetic acid clearance to GFR estimation using 100/creatinine (Cr), the Cockcroft-Gault formula (CGF) and the Modification of Diet in Renal Disease (MDRD) formula. The lines represent the regression line of best fit with Pearson's correlation coefficient $r_{(100 / \mathrm{Cr})}=0.74, r_{(\mathrm{CGF})}=0.80$ and $r_{(\mathrm{MDRD})}=0.87, P \leq 0.0001$

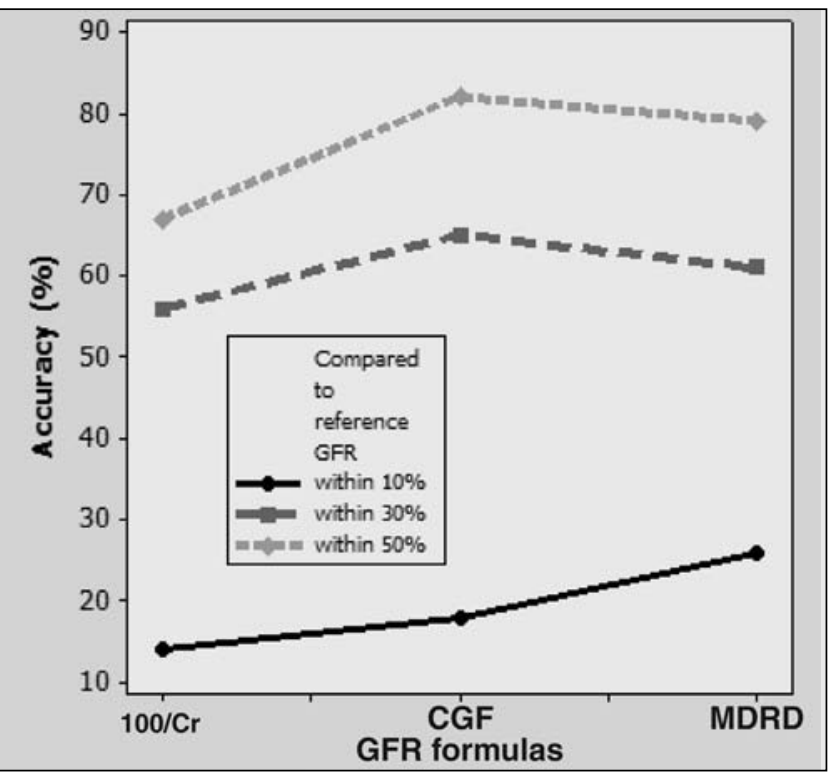

Figure 2) Accuracy of different creatinine (Cr)-based glomerular filtration rate (GFR) calculations expressed as the percentage of estimates with 10\%, 30\% and 50\% of the reference GFR as measured by $99 m$-technetium-diethylenetriamine pentaacetic acid clearance. The highest accuracy within 10\% was found for the Modification of Diet in Renal Disease (MDRD) formula at 26\%. CGF Cockcroft-Gault formula

The use of ${ }^{99 \mathrm{~m}} \mathrm{Tc}-\mathrm{DTPA}$ clearance as reference

Although inulin clearance is the gold standard for the measurement of GFR (11), this method is cumbersome and is used mainly as a research tool. In clinical practice, GFR measurements by radioisotope filtration markers have gained prominence because of their simplicity. The renal clearance of ${ }^{99 m}$ Tc-DTPA, 169-ytterbium-DTPA or ${ }^{125}$ I-iothalamate, administered as a single intravenous or subcutaneous injection, can be used to accurately measure GFR compared with using inulin clearance (12). All three radioisotopes are routinely used;

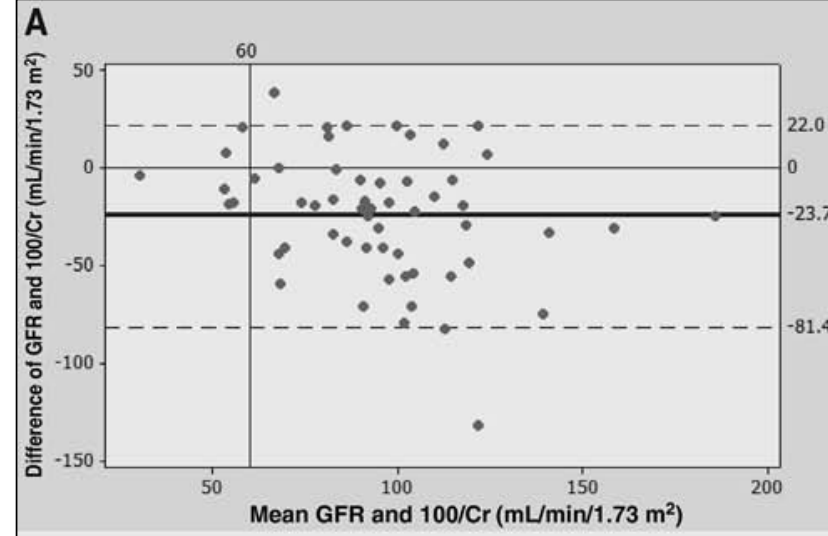

B
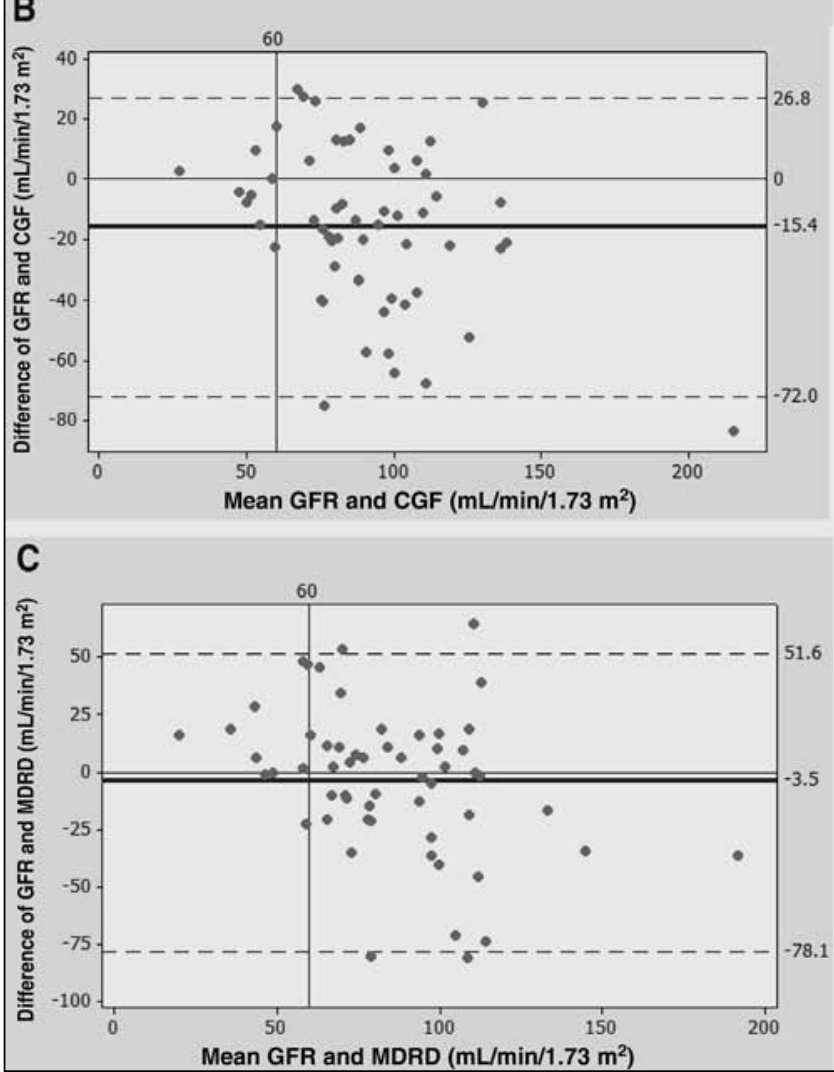

Figure 3) Bland-Altman comparison plots, which measure the agreement between glomerular filtration rate (GFR) measured by $99 m$-technetium-diethylenetriamine pentaacetic acid clearance, and A 100/creatinine (Cr), B the Cockcroft-Gault formula (CGF) and the C Modification of Diet in Renal Disease (MDRD) formula. The mean difference is indicated by the centre line; 95\% limits of agreement are indicated by the upper and lower lines. The MDRD formula shows the highest level of agreement with 99m-technetiumdiethylenetriamine pentaacetic acid clearance, overestimating renal function by $3 \mathrm{~mL} / \mathrm{min} / 1.73 \mathrm{~m}^{2}(P=0.414)$, while the CGF and 100/Cr overestimated renal function with significant difference $(P<0.001)$

however, it has been shown that 169-ytterbium-DTPA and ${ }^{125}$ I-iothalamate have higher clearance values compared with ${ }^{99 \mathrm{~m} T c-D T P A}$ or inulin (12). These radioisotope filtration markers are alternatives to inulin clearance as a standard reference for measurement of GFR (29), especially in routine clinical practice (30). 


\section{Comparison of GFR formulas in ALD patients}

The analysis showed that $99 \mathrm{~m}$ Tc-DTPA clearance correlated strongly with all three formulas. However, the scatter plot (Figure 1) illustrates the overestimation of $99 \mathrm{~m}$ Tc-DTPA clearance. The correlation between two measurement tools looks at how well the measurements are linearly related, not the agreement between them (31). The correlation also ignores the bias in each estimate of GFR and measures the relative agreement rather than the absolute agreement. Graphical representation, such as the Bland-Altman plot, is one alternative method preferred over correlation analysis to measure agreement in method comparison studies $(28,31)$. Using this method, we determined that the MDRD formula provides the narrowest $95 \%$ limits of agreement.

The MDRD formula was also more accurate in the prediction of GFR measured by ${ }^{99} \mathrm{~m}$ Tc-DTPA clearance as demonstrated by the lowest mean difference. This formula is based on age, sex and serum $\mathrm{Cr}$ levels (as is the more commonly used CGF), as well as serum albumin and serum urea nitrogen levels. ALD patients are often malnourished and have decreased albumin and urea production by the liver, that can lead to low serum albumin and urea levels (32). The formula seems to be structured to compensate for this. The other major difference between the MDRD formula and the CGF is that the MDRD formula does not factor in patient weight. Most ALD patients have moderate to significant ascites and edema, leading to increased weight. Patient weight is found in the numerator of the CGF, indicating that an overestimation in GFR would occur, which is exactly what is observed clinically.

Our results indicate that the MDRD formula may provide better estimates of ${ }^{99} \mathrm{~m}$ Tc-DTPA clearance on average compared with the more common CGF. The correlation analysis and

\section{REFERENCES}

1. La Vecchia C, Levi F, Lucchini F, Franceschi S, Negri E. Worldwide patterns and trends in mortality from liver cirrhosis, 1955 to 1990. Ann Epidemiol 1994;4:480-6.

2. Desai S, Peltekian KM. Canadian mortality rates for liver disease: Taking a closer look at ICD coding. Can J Public Health 2004;95:198-200.

3. Llach J, Gines P, Arroyo V, et al. Prognostic value of arterial pressure, endogenous vasoactive systems, and renal function in cirrhotic patients admitted to the hospital for the treatment of ascites. Gastroenterology 1988;94:482-7.

4. Serra MA, Puchades MJ, Rodriguez F, et al. Clinical value of increased serum creatinine concentration as predictor of short-term outcome in decompensated cirrhosis. Scand J Gastroenterol 2004;39:1149-53.

5. Giannini E, Botta F, Fumagalli A, et al. Can inclusion of serum creatinine values improve the Child-Turcotte-Pugh score and challenge the prognostic yield of the model for end-stage liver disease score in the short-term prognostic assessment of cirrhotic patients? Liver Int 2004;24:465-70.

6. Wiesner R, Edwards E, Freeman R, et al, United Network for Organ Sharing Liver Disease Severity Score Committee. Model for end-stage liver disease (MELD) and allocation of donor livers. Gastroenterology 2003;124:91-6.

7. Papadakis MA, Arieff AI. Unpredictability of clinical evaluation of renal function in cirrhosis. Prospective study. Am J Med 1987;82:945-52.

8. Takabatake T, Ohta H, Ishida Y, Hara H, Ushiogi Y, Hattori N. Low serum creatinine levels in severe hepatic disease. Arch Intern Med 1988;148:1313-5.

9. Carego L, Menon F, Angeli P, et al. Limitations of serum creatinine level and creatinine clearance as filtration markers in cirrhosis. Arch Intern Med 1994;154:201-5.
Bland-Altman plots provided estimates of the measurement errors, not indications of acceptability. It is the result of the measurement errors that decides the appropriateness of the methods. The MDRD formula provided limits of agreement that were clinically acceptable in our patient population.

\section{Clinical implications}

Using the CGF or 100/Cr method to estimate GFR in patients with ALD can lead to an overestimation of GFR by $15 \mathrm{~mL} / \mathrm{min} / 1.73 \mathrm{~m}^{2}$ and $24 \mathrm{~mL} / \mathrm{min} / 1.73 \mathrm{~m}^{2}$, respectively. In a clinical situation, this overestimation may result in overlooking renal dysfunction. Renal function has significant prognostic implications in the course of liver disease. It is a key factor in the determination of transplant status. As well, many medications that are used both pre- and postliver transplantation are cleared by the kidneys and, therefore, true renal function is an important factor in correct dosage and therapeutic monitoring.

If the clinician is unaware of the severity of renal dysfunction, further damage may be done to the kidneys through procedures and medications, possibly resulting in hepatorenal syndrome, which is associated with significant mortality $(33,34)$. The present study indicates that the MDRD formula for GFR estimation is more accurate on average than the CGF and $100 / \mathrm{Cr}$, providing clinically acceptable limits of agreement with small underestimated ${ }^{99 \mathrm{~m} T \mathrm{c}-\mathrm{DTPA} \text { clearance. }}$

ACKNOWLEDGEMENTS: Many thanks to Marlene Hudgins of the Nuclear Medicine Department and Helena MacKinnon, liver transplant recipient coordinator at the time of data collection, for their indispensable assistance in completing this project.

10. Sherman DS, Fish DN, Teitelbaum I. Assessing renal function in cirrhotic patients: Problems and pitfalls. Am J Kidney Dis 2003;41:269-78.

11. Cochetto DM, Tschanz C, Bjornsson TD. Decreased rate of creatinine production in patients with hepatic disease: Implications for estimation of creatinine clearance. Ther Drug Monit 1983;5:161-7.

12. Daugherty NA, Hammond KB, Osberg IM. Bilirubin interference with the kinetic Jaffe method for serum creatinine. Clin Chem 1978;24:392-3.

13. Mitch WE, Walser M, Buffington GA, Lemann J Jr. A simple method of estimating progression of chronic renal failure. Lancet 1976;ii:1326-8.

14. Cockcroft DW, Gault MH. Prediction of creatinine clearance from serum creatinine. Nephron 1976;16:31-41.

15. Levey AS, Bosch JP, Lewis JB, Greene T, Rogers N, Roth D. A more accurate method to estimate glomerular filtration rate from serum creatinine: A new prediction equation. Modification of Diet in Renal Disease Study Group. Ann Intern Med 1999;130:461-70.

16. Levey AS, Greene P, Burkhart J. Comprehensive assessment of the level of renal function at the initiation of dialysis in the MDRD study. J Am Soc Nephrol 1998;9:153A. (Abst)

17. Hallan S, Asbera A, Lindberg M, Johnsen H. Validation of the modification of diet in renal disease formula or estimating GFR with special emphasis on calibration. Am J Kidney Dis 2004;44:84-93.

18. Bedros FV, Kasiske BL. Estimating glomerular filtration rate from serum creatinine in renal transplant recipients. J Am Soc Nephrol 1998;9:666A. (Abst)

19. Poge U, Gerhardt T, Palmedo H, Klehr HU, Sauerbruch T, Woitas RP. MDRD equations for estimation of GFR in renal transplant recipients. Am J Transplant 2005;5:1306-11. 
20. Pawarode A, Fine DM, Thuluvath PJ. Independent risk factors and natural history of renal dysfunction in liver transplant recipients. Liver Transpl 2003;9:741-7.

21. Fairbanks KD, Eustace JA, Fine D, Thuluvath PJ. Renal function improves in liver transplant recipients when switched from a calcineurin inhibitor to sirolimus. Liver Transpl 2003;9:1079-85.

22. Yoshida EM, Marotta PJ, Greig PD, et al. Evaluation of renal function in liver transplant recipients receiving daclizumab (Zenapax), mycophenolate mofetil, and a delayed, low-dose tacrolimus regimen vs a standard-dose tacrolimus and mycophenolate mofetil regimen: A multicenter randomized clinical trial. Liver Transpl 2005;11:1064-72.

23. Skluzacek PA, Szewc RG, Nolan CR III, Riley DJ, Lee S, Pergola PE. Prediction of GFR in liver transplant candidates. Am J Kidney Dis 2003;42:1169-76.

24. Gonwa TA, Jennings L, Mai ML, Stark PC, Levey AS, Klintmalm GB. Estimation of glomerular filtration rates before and after orthotopic liver transplantation: Evaluation of current equations. Liver Transpl 2004;10:301-9.

25. Levey AS, Coresh J, Balk E, et al, National Kidney Foundation. National Kidney Foundation practice guidelines for chronic kidney disease: Evaluation, classification, and stratification. Ann Intern Med 2003;139:137-47.
26. Dubovsky EV, Russell CD. Quantitation of renal function with glomerular and tubular agents. Semin Nucl Med 1982;12:308-29.

27. Gunasekera RD, Allison DJ, Peters AM. Glomerular filtration rate in relation to extracellular fluid volume: Similarities between 99mTc-DTPA and inulin. Eur J Nucl Med 1996;23:49-54.

28. Bland JM, Altman DG. Measuring agreement in method comparison studies. Stat Methods Med Res 1999;8:135-60.

29. Perrone RD, Steinman TI, Beck GJ, et al. Utility of radioisotopic filtration markers in chronic renal insufficiency: Simultaneous comparison of ${ }^{125} \mathrm{I}$-iothalamate, ${ }^{169} \mathrm{Yb}$-DTPA, ${ }^{99 \mathrm{~m} T \mathrm{~T}-\mathrm{DTPA} \text {, and }}$ inulin. Am J Kidney Dis 1990;16:224-35.

30. Huttunen K, Huttunen NP, Koivula A, Ahonen A, Puukka R. 99mTc-DTPA - A useful clinical tool for the measurement of glomerular filtration rate. Scan J Urol Nephrol 1982;16:237-41.

31. Westgard JO. Points of care in using statistics in method comparison studies. Clin Chem 1998;44:2240-2.

32. Gecelter GR, Comer GM. Nutritional support during liver failure. Crit Care Clin 1995;11:675-83.

33. Gines A, Escorsell A, Gines P, et al. Incidence, predictive factors, and prognosis of hepatorenal syndrome in cirrhosis. Gastroenterology 1993;105:229-36.

34. Arroyo V, Guevara M, Gines P. Hepatorenal syndrome in cirrhosis: Pathogenesis and treatment. Gastroenterology 2002;122:1658-76. 


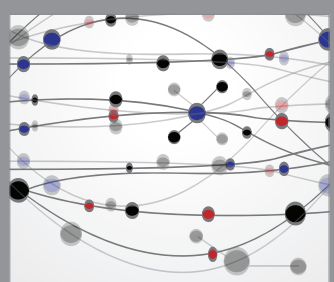

The Scientific World Journal
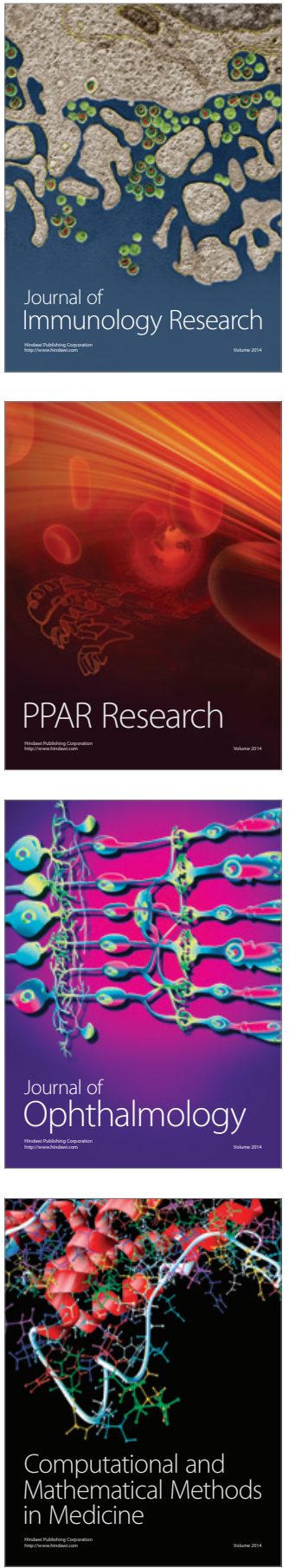

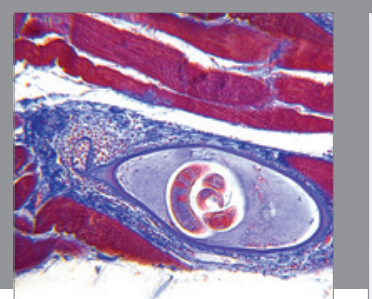

Gastroenterology Research and Practice

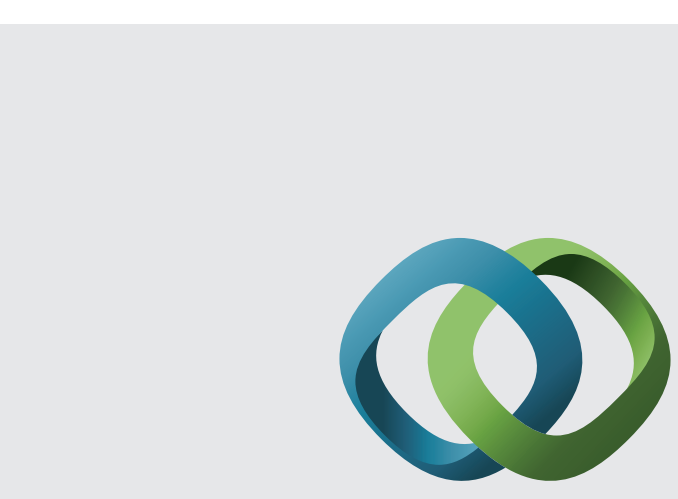

\section{Hindawi}

Submit your manuscripts at

http://www.hindawi.com
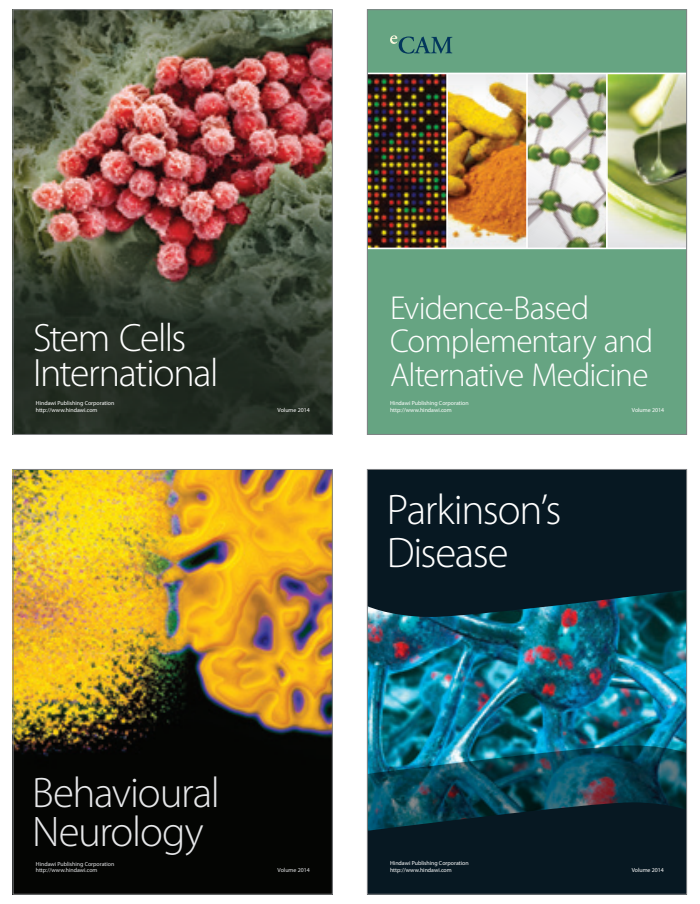
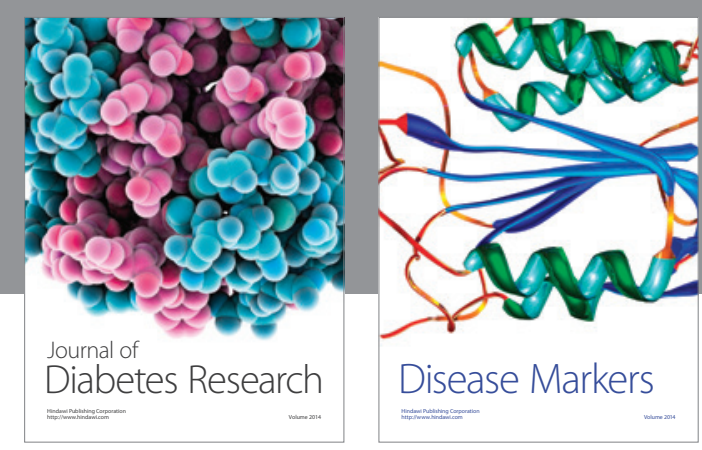

Disease Markers
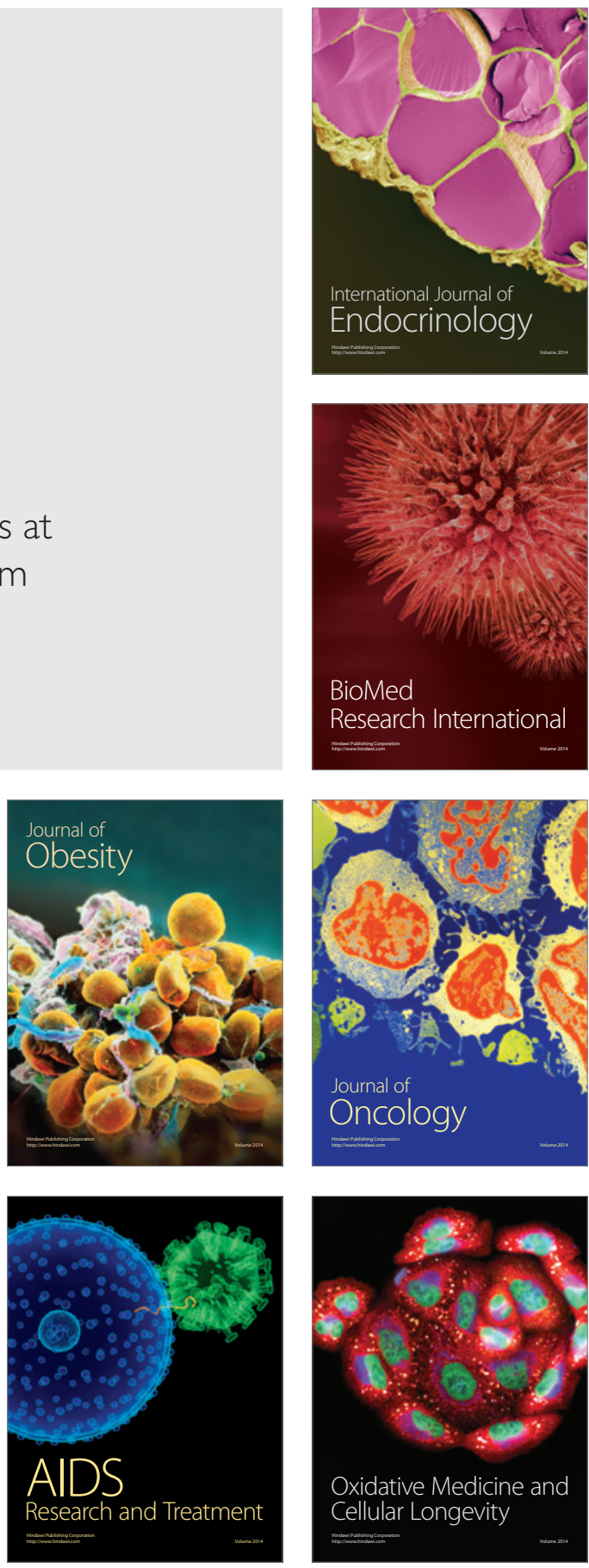